\title{
Self-sintering of BOS Filter Cake for Improved Recyclability
}

\author{
Raymond James LONGBOTTOM, ${ }^{11 *}$ Brian Joseph MONAGHAN, ${ }^{1)}$ Guangqing ZHANG, ${ }^{1)}$ David John PINSON ${ }^{2)}$ \\ and Sheng Jason $\mathrm{CHEW}^{21}$ \\ 1) School of Mechanical, Materials, Mechatronic and Biomedical Engineering and ARC Research Hub for Australian Steel \\ Manufacturing, University of Wollongong, Wollongong, NSW 2522 Australia. \\ 2) BlueScope Coke and Ironmaking Technology, Port Kembla, NSW 2505 Australia.
}

(Received on September 20, 2018; accepted on November 2, 2018)

\begin{abstract}
The self-sintering of BOS filter cake has been investigated by studying its oxidation in air between 100 to $1000^{\circ} \mathrm{C}$. The aim of the study was to gain an understanding of the self-sintering of the BOS filter cake in stockpiles, in terms of what reactions occurred, and how strength was developed in the filter cake during self-sintering.

Upon heating, the BOS filter cake underwent a sequence of drying, oxidation and calcination events. The self-sintering process was driven by the oxidation of very fine (200-300 nm) particles of metallic iron and wüstite at low temperatures. Reactions in self-sintering were found to be the oxidation of metallic iron and wüstite to hematite and zinc ferrite, beginning at approximately $120^{\circ} \mathrm{C}$ and largely complete by 500 $600^{\circ} \mathrm{C}$. Phase analysis, thermodynamic modelling and enthalpy measurements were used to propose a probable reaction path consistent with the observed reaction products. These exothermic oxidation reactions at low temperatures provided the energy required to heat the stockpiles to drive self-sintering.

Bonding within the reacted filter cake was from a network of particle-particle bonds formed between the very fine iron oxide particles in the matrix during oxidation at elevated temperatures. Exposure of the BOS filter cake to temperatures above $600^{\circ} \mathrm{C}$ under oxidising conditions is likely sufficient to form adequately strong material for transport and recycling in the BOS. Fluxes played little role in the development of the bonding within the filter cake.
\end{abstract}

KEY WORDS: BOS dust; recycling; by-products; self-sintering; characterisation.

\section{Introduction}

Research into on-plant recycling of by-products has been driven by the desire to improve the environmental and economic sustainability of the steel industry. ${ }^{1,2)}$ One of the largest by-product streams in an integrated steel plant is dust from the basic oxygen steelmaking (BOS) process. Significant amounts of dust are formed in the BOS, where oxygen blown at supersonic velocities impacts on the liquid steel.

This dust is made up of droplets of liquid steel, slag and fine particulates from the added fluxes. ${ }^{1-4)}$ As steelmaking temperatures are in excess of $1600^{\circ} \mathrm{C}$, elements such as zinc can volatilise from the bath and enter the gas phase. As the gas phase is cooled, these volatilised metals can condense as separate particles or onto existing dust particles. Subsequent recycling of BOS dust back into the steelmaking route can therefore result in a recirculating and increasing zinc load that can result in process issues. Knowledge of the form in which the iron and zinc are found within the BOS dust is crucial in understanding how to best recycle the dust or how best to process it for recycling. ${ }^{2,3,5)}$

A well-known issue with steel plant by-products is their high variability. ${ }^{1,2,5,6)}$ In the case of BOS dust, the composi-

\footnotetext{
* Corresponding author: E-mail: rayl@uow.edu.au

DOI: https://doi.org/10.2355/isijinternational.ISIJINT-2018-627
}

tion, phase content and particle size can change from heat to heat, depending on the target and hot metal (and scrap) composition, as well as within a single heat, depending on the blowing conditions and any additions made (fluxes and coolants). This makes these materials difficult to characterise and can cause issues in reuse and recycling.

BOS dust is often removed from the off-gas using a wet scrubbing process, forming a slurry that requires dewatering for reuse. The BOS dust slurry may be dewatered using a tube press producing a low moisture filter cake. When stored in stockpiles prior to recycling, experience has shown that the BOS filter cake has a tendency to self-sinter, ${ }^{7,8)}$ which is likely a result of exothermic oxidation reactions. The self-sintered material is preferred for recycling as it has better handling/transport properties, with higher strength and larger particle size, when compared to the original filter cake. The higher strength and particle size allows the selfsintered material to be fed directly (recycled) into the BOS as a coolant. Prior to adding to the BOS, the self-sintered filtercake is screened, with the $+4 \mathrm{~mm}$ fraction fed to the BOS. Undersize $(-4 \mathrm{~mm})$ may be recycled elsewhere on plant, but at a low rate (commonly via ore sintering). Enhancing the self-sintering agglomeration of the BOS filter cake in the stockpiles may allow more material to be recycled to the BOS. This should lead to a decrease in production costs while also improving the environmental 
performance of the plant.

Better understanding of the oxidation and self-sintering behaviour of the BOS filter cake will allow optimisation of this process and improved recyclability via the BOS coolant route. To achieve this, the BOS filter cake from the BlueScope steelworks has been characterised by several techniques, including scanning electron microscopy (SEM), X-ray diffraction (XRD), thermo-gravimetric analysis (TGA) and differential scanning calorimetry (DSC). Freshly produced BOS filter cake was characterised and compared to samples sintered in two different ways. These sintered BOS filter cake samples were either processed in a TGA or self-sintered in the plant stockpiles.

The main objective of this study was to improve understanding of the self-sintering of the BOS filter cake, so that it might be better utilised by on-plant recycling to the BOS. The approach taken was to use an external heat source to start the BOS filter cake self-sintering process, to study the reactivity in air and understand what conditions are required for the formation of bonds that lead to increased strength within the BOS filter cake.

\section{Experimental}

The approach used for this study was to start with characterisation of the unreacted BOS filter cake, using XRD and SEM. The reactivity of the BOS filter cake was then studied non-isothermally during heating to $1000^{\circ} \mathrm{C}$ in air, in both a large sample TGA and in a small sample TGA-DSC apparatus. Selected samples heated in the large sample TGA were rapidly-cooled at specific temperatures during the heating programme. These samples were characterised to examine the effect of temperature on the phase distribution, the microstructure and the extent of bond formation. The microstructures and bonding formed were compared against self-sintered samples taken from the plant stockpiles. Two types of self-sintered samples were characterised, one with and one without adequate strength for recycling.

\subsection{Large Sample TGA}

A large scale TGA system, as shown in Fig. 1, was used to measure weight change during reaction of the BOS filter

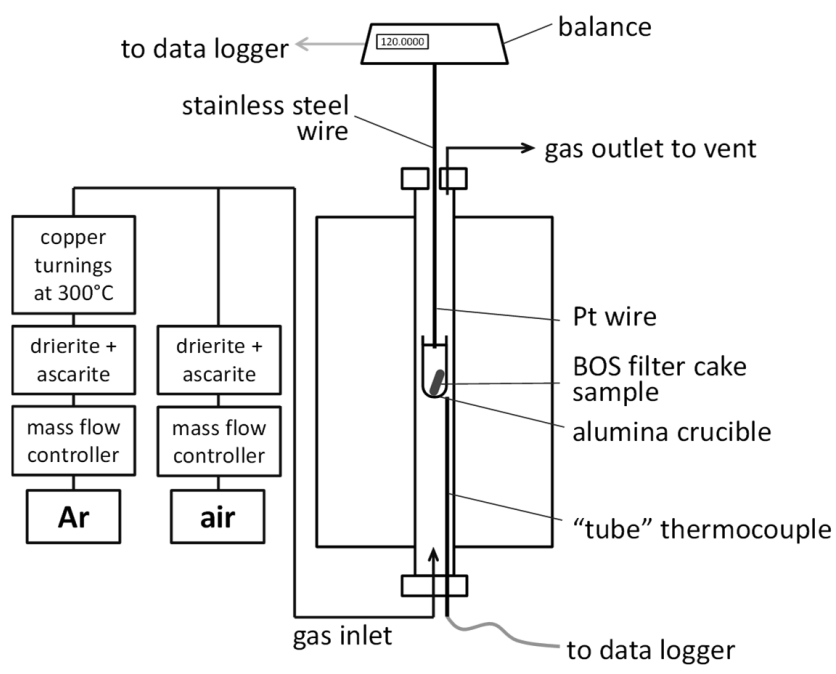

Fig. 1. Schematic of large sample TGA set-up. cake with air while heating to $1000^{\circ} \mathrm{C}$. A sample of fresh, unreacted BOS filter cake with a nominal mass of $20 \mathrm{~g}$ (typically a single "biscuit") was placed in an alumina crucible hung from the balance. To ensure good contact between gas and sample, there were twelve $8 \mathrm{~mm}$ holes around the bottom circumference of the crucible.

Samples were initially held at $100^{\circ} \mathrm{C}$ for 70 minutes in Ar. The system was then heated at $10^{\circ} \mathrm{C} / \mathrm{min}$ to $1000^{\circ} \mathrm{C}$ under air flowing at $1 \mathrm{~L} / \mathrm{min}$. It was held at $1000^{\circ} \mathrm{C}$ in the flowing air for a further 30 minutes before cooling under Ar. The air was purified by passing through drierite and ascarite prior to entering the furnace. The Ar was further cleaned by passing it through $\mathrm{Cu}$ turnings at $300^{\circ} \mathrm{C}$. The sample temperature was calibrated using a representative sample with an embedded thermocouple which underwent the same heating program used for the TGA experiments.

The weight of the sample was logged once a second during heating and the data from the TGA tests were converted to a dimensionless fractional weight change to allow better comparison between samples. The calculated fractional weight change (FWC) was used to characterise the extent of reaction of the sample according to (1),

$$
\mathrm{FWC}=\left(\frac{\mathrm{W}_{\mathrm{t}}-\mathrm{W}_{\mathrm{o}}}{\mathrm{W}_{\mathrm{o}}}\right)
$$

where $\mathrm{W}_{\mathrm{o}}$ and $\mathrm{W}_{\mathrm{t}}$ are the initial mass and the mass of a sample at time $t$, respectively in grams.

\subsection{Rapidly Cooled Samples}

To help better understand what reactions were occurring within the BOS filter cake during oxidation, samples were quenched from different stages during the heating in air. Specifically, samples were rapidly cooled from $400^{\circ} \mathrm{C}$, $600^{\circ} \mathrm{C}, 800^{\circ} \mathrm{C}$ and $1000^{\circ} \mathrm{C}$. These temperatures were chosen to investigate specific features in the TGA or TGA-DSC curves.

\subsection{TGA-DSC Testing}

The reactivity of the BOS filter cake was also examined using TGA-DSC testing, using a Netzsch STA449 F5 Jupiter. Samples of fresh BOS filter cake were heated at $5^{\circ} \mathrm{C} /$ $\mathrm{min}, 10^{\circ} \mathrm{C} / \mathrm{min}$ and $20^{\circ} \mathrm{C} / \mathrm{min}$ to $1000^{\circ} \mathrm{C}$ under air flowing at $120 \mathrm{~mL} / \mathrm{min}$. Different heating rates were used to examine any possible changes in the temperatures of features that occurred in the weight change and DSC curves. The measured data were analysed using the Netzsch Proteus Analysis software version 6.1. The sample size was a nominal $100 \mathrm{mg}$, and the samples were contained within platinumrhodium crucibles with a thin alumina liner and a platinumrhodium lid. No drying step (as carried out for the large sample TGA) was used in these tests as the smaller sample size used in the TGA-DSC generally allowed the samples to dry quickly enough to maintain separation between the drying and low temperature oxidation steps.

\subsection{Characterisation}

Samples for XRD were prepared by hand grinding using a mortar and pestle. XRD analysis of the BOS filter cake was carried out using a GBC-MMA diffractometer. $\mathrm{Cu}-\mathrm{K} \alpha$ radiation was used, with the X-ray tube set to $1 \mathrm{~kW}$ of power ( $35 \mathrm{kV}$ and $28.6 \mathrm{~mA}$ ), with a step size of $0.02^{\circ}$ and 
a scan rate of $1 \%$ min over the $2 \theta$ range from $20-80^{\circ}$. For simple peak identification and phase analysis, the diffraction patterns were analysed using the Traces (v 6.0) software. Attempts to quantify the diffraction patterns were conducted using the Panalytical X'Pert Highscore Plus software. The nature of these samples made fully quantitative analysis difficult. The results from XRD in this study are presented as semi-quantitative.

Cross-sections of samples were examined using scanning electron microscopy (SEM) with energy dispersive spectroscopy (EDS) for elemental analysis. The mounted samples were sectioned and then ground and polished to a $1 \mu \mathrm{m}$ diamond finish before carbon coating. High resolution microscopy was carried out using a FEGSEM, a JEOL JSM$7001 \mathrm{~F}$, which was equipped with an Oxford Instruments 80 $\mathrm{mm}^{2}$ EDS detector.

XRF bulk analysis was carried out using a fused bead technique. The bead was analysed using a SPECTRO XEPOS energy dispersive polarization XRF spectrometer with a 50 Watt Pd end-window tube for excitation. Beads were prepared from a nominal $0.4 \mathrm{~g}$ of sample and $2.4 \mathrm{~g}$ of flux. The flux used contained lithium metaborate $\left(\mathrm{LiBO}_{2}\right)$ and lithium tetraborate $\left(\mathrm{Li}_{2} \mathrm{~B}_{4} \mathrm{O}_{7}\right)$, at a ratio of $57: 43 \mathrm{LiBO}_{2}$ : $\mathrm{Li}_{2} \mathrm{~B}_{4} \mathrm{O}_{7}$.

\section{Results and Discussion}

The main goal of this study was to develop the understanding of the reaction behaviour of the BOS filter cake during self-sintering. As such, the first step was to characterise it in the fresh, unreacted state. The reactivity of the BOS filter cake samples during heating in air was then measured. The reactions that occurred were then analysed through a variety of techniques, including post experimental characterisation, thermodynamic analysis and measurement of the enthalpy of reaction. Finally, the bonding formed within the BOS filter cake during the self-sintering reactions was examined.

\subsection{Characterisation of Unreacted BOS Filter Cake}

The composition of the unreacted BOS filter cake (as measured by XRF) and its phase content (as measured by quantitative XRD) are given in Tables $\mathbf{1}$ and $\mathbf{2}$ respectively. The unreacted BOS filter cake contained a number of iron bearing phases, zinc oxide and fluxes. The predominant iron bearing phases were wüstite and metallic iron. It was difficult to differentiate between magnetite and zinc ferrite (or a solution of both) by XRD, hence these phases are also reported as a combined spinel total. From review of Tables
1 and 2, it can be seen that there is a discrepancy between the $\mathrm{Zn}$ content as measured by XRF and XRD. It is thought that this discrepancy is at least partly a function of the likely small crystallite size of the $\mathrm{ZnO}$ phase, which may be indicated by the large amorphous (or non-bulk crystalline) proportion given in Table 2 .

There was some variation in composition between samples of the unreacted material. However, this variation was not extensively studied. There was little variation in the total amount of iron and iron oxides in the unreacted BOS filter cake samples when characterised by XRF. On the other hand, when analysed by XRD, variation between samples in the ratio of wüstite to metallic iron was noted.

From low magnification micrographs (Fig. 2(a)), it can be seen that the unreacted BOS filter cake consists of a few larger particles in a fine matrix phase. At high magnifications (Fig. 2(b)), the matrix could be seen to consist of an agglomeration of individual, round particles, in the size range $200-500 \mathrm{~nm}$. The larger particles were either spherical metallic iron or iron oxide particles in the range 5-50 $\mu \mathrm{m}$ or more irregularly shaped flux particles in the range 5-100 $\mu \mathrm{m}$. Both limestone and dolomite were identified through EDS.

\subsection{Reactivity of BOS Filter Cake}

The large sample TGA tests were conducted on a single piece of unreacted BOS filter cake. In these tests, the samples were initially dried by heating in $\mathrm{Ar}$ to $100^{\circ} \mathrm{C}$ and then holding at this temperature for 70 minutes. This drying step was carried out to establish a common starting point for the test with regard to sample moisture. The dried sample was then heated in air at $10^{\circ} \mathrm{C} / \mathrm{min}$ to $1000^{\circ} \mathrm{C}$. A typical weight change curve from using the large scale TGA is given in Fig. 3. These plots were used to assist identifying important temperature-reaction features.

Smaller samples were tested using a TGA-DSC. Typical weight change and DSC curves for heating a nominal $100 \mathrm{mg}$ sample to $1000^{\circ} \mathrm{C}$ in air are given in Fig. 4. The FWC changes from the TGA-DSC were similar to those of the large sample TGA, the main difference being that the weight change features in the TGA-DSC appear to occur at lower temperatures and over smaller temperature ranges. This might be expected to occur with the much smaller samples used in the TGA-DSC technique. The use of smaller samples minimised temperature gradients within the sample and any possible mass transfer effects that might be occurring in the large sample TGA. In general, and from a temperature perspective, the exo- or endothermic features in the DSC curves align and were consistent with features

Table 1. Composition of fresh, unreacted BOS filter cake, as measured by XRF in mass\%.

\begin{tabular}{ccccccccccc}
\hline $\mathrm{MgO}$ & $\mathrm{Al}_{2} \mathrm{O}_{3}$ & $\mathrm{SiO}_{2}$ & $\mathrm{P}_{2} \mathrm{O}_{5}$ & $\mathrm{SO}_{3}$ & $\mathrm{~K}_{2} \mathrm{O}$ & $\mathrm{CaO}$ & $\mathrm{TiO}_{2}$ & $\mathrm{MnO}$ & $\mathrm{Fe}_{2} \mathrm{O}_{3}$ & $\mathrm{ZnO}$ \\
\hline 1.9 & $<0.5$ & 2.3 & $<0.5$ & $<0.5$ & $<0.5$ & 4.7 & 0.0 & 0.7 & 72.7 & 16.7 \\
\hline
\end{tabular}

Table 2. Phases present within unreacted BOS filter cake and their content, as measured by XRD in mass $\%$.

\begin{tabular}{ccccccccc}
\hline $\begin{array}{c}\text { quartz } \\
\mathrm{SiO}_{2}\end{array}$ & $\begin{array}{c}\text { calcite } \\
\mathrm{CaCO}_{3}\end{array}$ & $\begin{array}{c}\text { lime } \\
\mathrm{CaO}\end{array}$ & $\begin{array}{c}\text { zincite } \\
\mathrm{ZnO}\end{array}$ & $\begin{array}{c}\text { wüstite } \\
\mathrm{FeO}\end{array}$ & $\begin{array}{c}\text { metallic } \\
\mathrm{Fe}\end{array}$ & $\begin{array}{c}\text { hematite } \\
\mathrm{Fe}_{2} \mathrm{O}_{3}\end{array}$ & $\begin{array}{c}\text { total spinel } \\
\mathrm{Fe}_{3} \mathrm{O}_{4}+\mathrm{ZnFe}_{2} \mathrm{O}_{4}\end{array}$ & $\begin{array}{c}\text { Amorphous/non-bulk } \\
\text { crystalline }\end{array}$ \\
\hline 5.0 & 6.8 & $<1$ & 1.2 & 29.8 & 16.9 & 0 & 11.0 & 29.1 \\
\hline
\end{tabular}




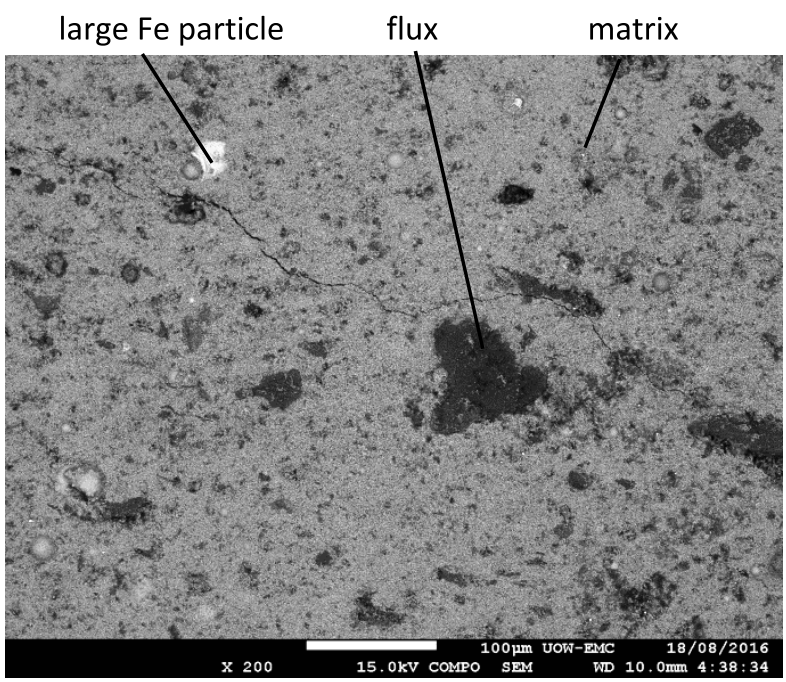

(a)

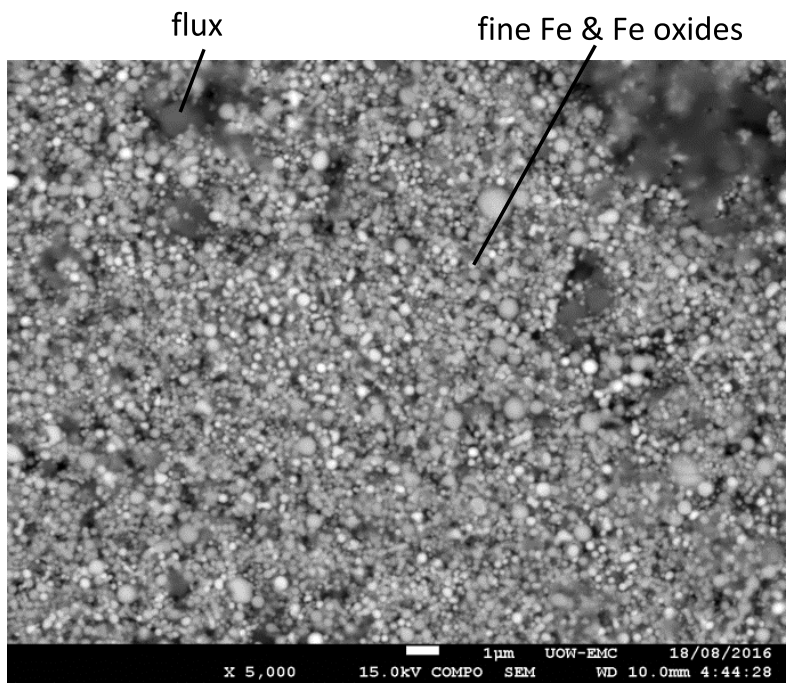

(b)

Fig. 2. Micrographs of the unreacted BOS filter cake sample. (a) Low magnification back scattered electron images, the scale bar is $100 \mu \mathrm{m}$; and (b) High magnification back scattered electron images, the scale bar is $1 \mu \mathrm{m}$.

observed in the FWC curve.

The BOS filter cake behaviour during heating in air had a characteristic and repeatable nature. Similar behaviour was found in both the large sample TGA and the small sample TGA-DSC. This characteristic nature was surprising. Based on historical bulk composition analysis and the literature, ${ }^{1,6,9)}$ it was expected that the BOS filter cake would be quite variable in both its content and behaviour. While there was variation in composition between samples of the unreacted material, this appeared to have little effect on the filter cake oxidation behaviour. Although the BOS filter cake was comprised mainly of metallic iron and wüstite, there was variation in their proportions in the unreacted BOS filter cake. It is likely that the presence of these phases in the BOS filter cake, and not their precise proportions, is responsible for the characteristic behaviour.

The small particle size of the unreacted BOS filter cake also likely plays a role in determining the characteristic

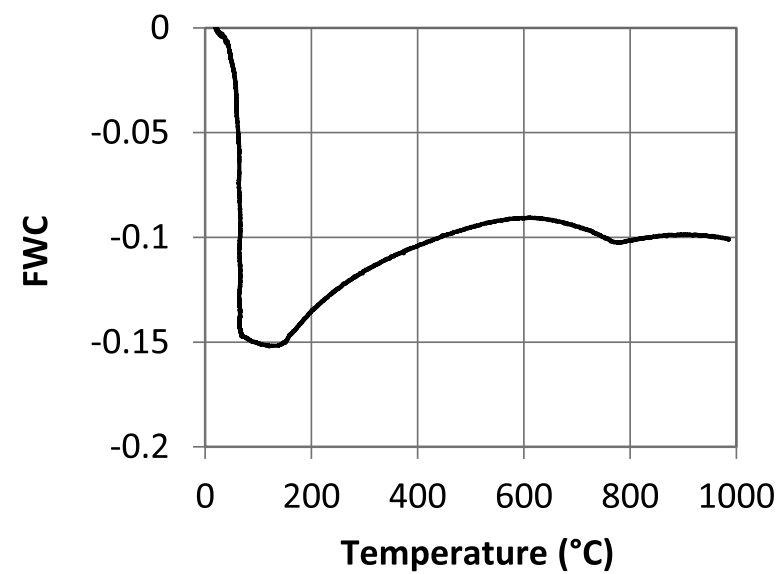

Fig. 3. Typical reactivity measurement for fresh BOS filter cake heated to $1000^{\circ} \mathrm{C}$ in air in the large sample TGA.
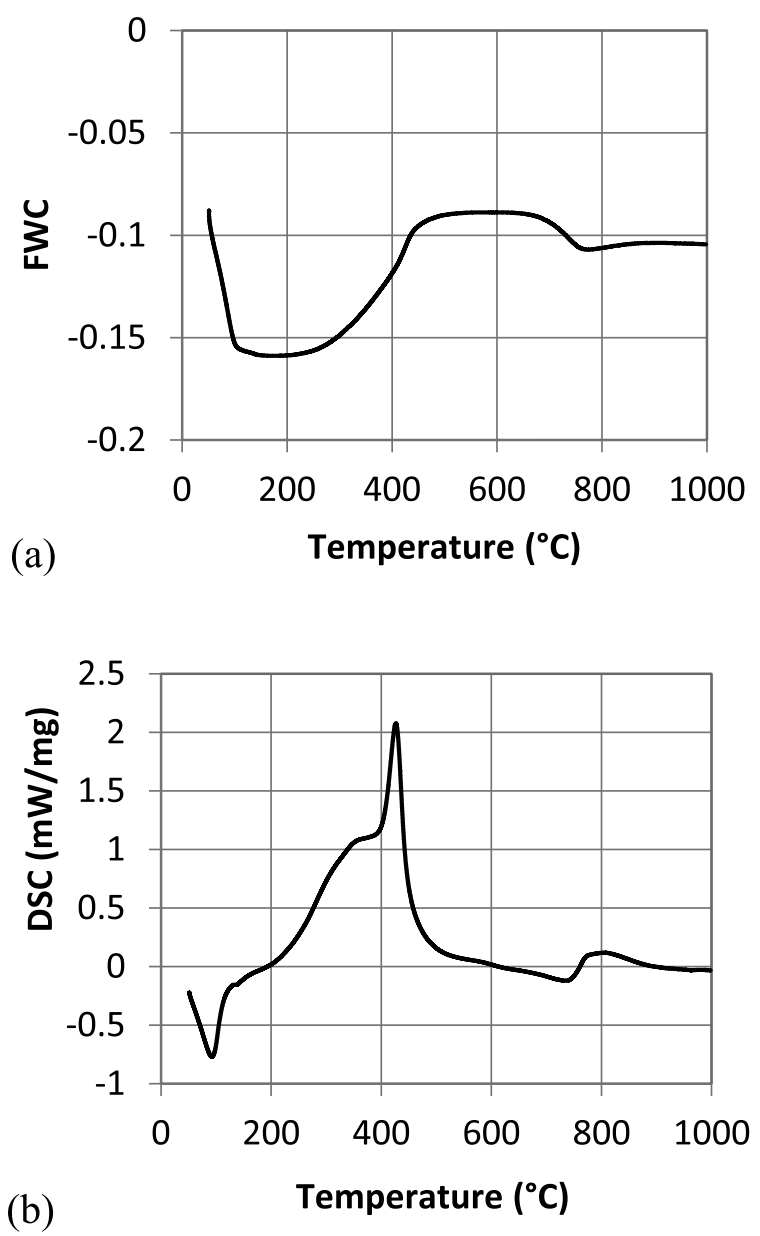

Fig. 4. TGA-DSC results for fresh BOS filter cake heated to $1000^{\circ} \mathrm{C}$ in air. (a) Weight change curve; and (b) DSC curve for a sample heated at $10^{\circ} \mathrm{C} / \mathrm{min}$ (exothermic is positive).

behaviour. The low temperature reactivity was likely to be primarily due to the very fine particle size of the wüstite and metallic iron in the matrix. As the fine particles of metallic iron and wüstite have high reactivity and comprise the majority of the BOS filter cake, it may be expected to dominate the reaction behaviour of the BOS filter cake.

This characteristic behaviour of the BOS filter cake during heating in air was a complex, multi-step process, and can be seen as the behaviour of the BOS filter cake during 
the self-sintering process. The steps in the process, along with typical temperature ranges are:

Step 1. Drying of the sample at $\mathrm{T}<\sim 120^{\circ} \mathrm{C}$. This was observed by a decrease in the sample weight and an endothermic peak in the DSC curve.

Step 2. Oxidation of the initial metallic iron and wüstite mixture to hematite and zinc ferrite, at $\sim 120$ $130^{\circ} \mathrm{C}<\mathrm{T}<\sim 600^{\circ} \mathrm{C}$. This was associated with an increase in the weight of the sample, and a large exothermic peak. It appeared that the oxidation of the metallic iron and wüstite did not occur until after the water has been removed from the sample, making it likely that the moisture level of the BOS filter cake is an important parameter in the self-sintering of the BOS filter cake.

Step 3. Calcination of dolomite at $\sim 600-620^{\circ} \mathrm{C}<\mathrm{T}$ $<770^{\circ} \mathrm{C}$. This was observed by a decrease in sample weight and a small endothermic peak.

Step 4. A very small weight gain at $\sim 730-770^{\circ} \mathrm{C}<\mathrm{T}<$ $\sim 900^{\circ} \mathrm{C}$, likely caused by further oxidation of the large iron/iron oxide particles.

Step 5. A very small decrease in sample weight at $\mathrm{T}>$ $900^{\circ} \mathrm{C}$, possibly caused by calcination of unburnt lime.

The methodology used to identify what reactions were occurring in each of these steps is outlined in turn.

\subsection{Step 1 .}

The BOS filter cake is known to contain somewhere in the order of 15 mass $\%$ moisture. This corresponds well with the weight change recorded in the large sample TGA. Evaporation of moisture is endothermic. ${ }^{10)}$ The temperature range also matches well with the boiling point of water $\left(100^{\circ} \mathrm{C}\right)$. Hence, this step was identified as drying of the BOS filter cake.

\subsection{Step 2.}

Both the weight increase and the exothermic peak for this step were by far the largest. It represents both the main oxidation step and likely main energy source for self-sintering. Understanding what is occurring during Step 2 is vital for better understanding of the self-sintering of the BOS filter cake.

Several reactions, given in Eqs. (2)-(9), were proposed based on the known starting phases and proportions from the characterisation of the unreacted BOS filter cake and their expected behaviour under oxidising conditions.

$$
\begin{array}{r}
\mathrm{Fe}_{(\mathrm{s})}+1 / 2 \mathrm{O}_{2(\mathrm{~g})}=\mathrm{FeO}_{(\mathrm{s})} \\
\mathrm{Fe}_{(\mathrm{s})}+2 / 3 \mathrm{O}_{2(\mathrm{~g})}=1 / 3 \mathrm{Fe}_{3} \mathrm{O}_{4(\mathrm{~s})} \\
\mathrm{FeO}_{(\mathrm{s})}+1 / 6 \mathrm{O}_{2(\mathrm{~g})}=1 / 3 \mathrm{Fe}_{3} \mathrm{O}_{4(\mathrm{~s})} \\
1 / 3 \mathrm{Fe}_{3} \mathrm{O}_{4(\mathrm{~s})}+1 / 12 \mathrm{O}_{2(\mathrm{~g})}=1 / 2 \mathrm{Fe}_{2} \mathrm{O}_{3(\mathrm{~s})} \\
\mathrm{Fe}_{2} \mathrm{O}_{3}+\mathrm{ZnO}_{(\mathrm{s})}=\mathrm{ZnFe}_{2} \mathrm{O}_{4(\mathrm{~s})} \\
\frac{2}{3} \mathrm{Fe}_{3} \mathrm{O}_{4(\mathrm{~s})}+1 / 6 \mathrm{O}_{2}+\mathrm{ZnO}_{(\mathrm{s})}=\mathrm{ZnFe}_{2} \mathrm{O}_{4(\mathrm{~s})} \\
2 \mathrm{FeO}_{(\mathrm{s})}+1 / 2 \mathrm{O}_{2}+\mathrm{ZnO}_{(\mathrm{s})}=\mathrm{ZnFe}_{2} \mathrm{O}_{4(\mathrm{~s})}
\end{array}
$$

These reactions were grouped into a number of different possible reaction schemes that were considered for this step, as shown in Table 3. These schemes were proposed based on reactions likely to occur during the oxidation of the BOS filter cake. Each of the schemes was considered against three criteria. These were:

1. Consideration of the phases present in the sample before and after reaction;

2. Thermodynamic modelling of the $\mathrm{Fe}-\mathrm{Zn}-\mathrm{O}_{2}$ system using FactSage; and

3. Comparison between measured and expected enthalpies of reaction.

The rapidly cooled samples were found to show distinctive shrinking core behaviour, ${ }^{11)}$ with both different phases and different morphologies found in the outer layer and inner core. A typical example of this shrinking core is given in Fig. 5 and quantitative XRD results are given in Table 4. From Table 4 it can be seen that hematite and a spinel phase (either magnetite, zinc ferrite or a solid solution of the two) were formed at all temperatures and were present in increasing proportions with increasing temperature. At $600^{\circ} \mathrm{C}$, approximately half of the initial $\mathrm{ZnO}$ content of the

\begin{tabular}{|c|c|c|}
\hline Reaction Scheme & Equations below $570^{\circ} \mathrm{C}$ & Equations above $570^{\circ} \mathrm{C}$ \\
\hline 1 & $\begin{array}{c}\mathrm{Fe}_{(\mathrm{s})}+2 / 3 \mathrm{O}_{2(\mathrm{~g})}=1 / 3 \mathrm{Fe}_{3} \mathrm{O}_{4(\mathrm{~s})} \\
\mathrm{FeO}_{(\mathrm{s})}+1 / 6 \mathrm{O}_{2(\mathrm{~g})}=1 / 3 \mathrm{Fe}_{3} \mathrm{O}_{4(\mathrm{~s})} \\
1 / 3 \mathrm{Fe}_{3} \mathrm{O}_{4(\mathrm{~s})}+1 / 12 \mathrm{O}_{2(\mathrm{~g})}=1 / 2 \mathrm{Fe}_{2} \mathrm{O}_{3(\mathrm{~s})}\end{array}$ & $\begin{array}{c}\mathrm{Fe}_{(\mathrm{s})}+1 / 2 \mathrm{O}_{2(\mathrm{~g})}=\mathrm{FeO}_{(\mathrm{s})} \\
\mathrm{FeO}_{(\mathrm{s})}+1 / 6 \mathrm{O}_{2(\mathrm{~g})}=1 / 3 \mathrm{Fe}_{3} \mathrm{O}_{4(\mathrm{~s})} \\
1 / 3 \mathrm{Fe}_{3} \mathrm{O}_{4(\mathrm{~s})}+1 / 12 \mathrm{O}_{2(\mathrm{~g})}=1 / 2 \mathrm{Fe}_{2} \mathrm{O}_{3(\mathrm{~s})}\end{array}$ \\
\hline 2 & $\begin{array}{c}\mathrm{Fe}_{(\mathrm{s})}+2 / 3 \mathrm{O}_{2(\mathrm{~g})}=1 / 3 \mathrm{Fe}_{3} \mathrm{O}_{4(\mathrm{~s})} \\
\mathrm{FeO}_{(\mathrm{s})}+1 / 6 \mathrm{O}_{2(\mathrm{~g})}=1 / 3 \mathrm{Fe}_{3} \mathrm{O}_{4(\mathrm{~s})}\end{array}$ & $\begin{array}{c}\mathrm{Fe}_{(\mathrm{s})}+1 / 2 \mathrm{O}_{2(\mathrm{~g})}=\mathrm{FeO}_{(\mathrm{s})} \\
\mathrm{FeO}_{(\mathrm{s})}+1 / 6 \mathrm{O}_{2(\mathrm{~g})}=1 / 3 \mathrm{Fe}_{3} \mathrm{O}_{4(\mathrm{~s})}\end{array}$ \\
\hline 3 & $\begin{array}{c}\mathrm{Fe}_{(\mathrm{s})}+2 / 3 \mathrm{O}_{2(\mathrm{~g})}=1 / 3 \mathrm{Fe}_{3} \mathrm{O}_{4(\mathrm{~s})} \\
\mathrm{FeO}_{(\mathrm{s})}+1 / 6 \mathrm{O}_{2(\mathrm{~g})}=1 / 3 \mathrm{Fe}_{3} \mathrm{O}_{4(\mathrm{~s})} \\
1 / 3 \mathrm{Fe}_{3} \mathrm{O}_{4(\mathrm{~s})}+1 / 12 \mathrm{O}_{2(\mathrm{~g})}=1 / 2 \mathrm{Fe}_{2} \mathrm{O}_{3(\mathrm{~s})} \\
\mathrm{Fe}_{2} \mathrm{O}_{3}+\mathrm{ZnO}_{(\mathrm{s})}=\mathrm{ZnFe}_{2} \mathrm{O}_{4(\mathrm{~s})}\end{array}$ & $\begin{array}{c}\mathrm{Fe}_{(\mathrm{s})}+1 / 2 \mathrm{O}_{2(\mathrm{~g})}=\mathrm{FeO}_{(\mathrm{s})} \\
\mathrm{FeO}_{(\mathrm{s})}+1 / 6 \mathrm{O}_{2(\mathrm{~g})}=1 / 3 \mathrm{Fe}_{3} \mathrm{O}_{4(\mathrm{~s})} \\
1 / 3 \mathrm{Fe}_{3} \mathrm{O}_{4(\mathrm{~s})}+1 / 12 \mathrm{O}_{2(\mathrm{~g})}=1 / 2 \mathrm{Fe}_{2} \mathrm{O}_{3(\mathrm{~s})} \\
\mathrm{Fe}_{2} \mathrm{O}_{3}+\mathrm{ZnO}_{(\mathrm{s})}=\mathrm{ZnFe}_{2} \mathrm{O}_{4(\mathrm{~s})}\end{array}$ \\
\hline 4 & $\begin{array}{c}\mathrm{Fe}_{(\mathrm{s})}+2 / 3 \mathrm{O}_{2(\mathrm{~g})}=1 / 3 \mathrm{Fe}_{3} \mathrm{O}_{4(\mathrm{~s})} \\
\mathrm{FeO}_{(\mathrm{s})}+1 / 6 \mathrm{O}_{2(\mathrm{~g})}=1 / 3 \mathrm{Fe}_{3} \mathrm{O}_{4(\mathrm{~s})} \\
2 / 3 \mathrm{Fe}_{3} \mathrm{O}_{4(\mathrm{~s})}+1 / 6 \mathrm{O}_{2}+\mathrm{ZnO}_{(\mathrm{s})}=\mathrm{ZnFe}_{2} \mathrm{O}_{4(\mathrm{~s})}\end{array}$ & $\begin{array}{c}\mathrm{Fe}_{(\mathrm{s})}+1 / 2 \mathrm{O}_{2(\mathrm{~g})}=\mathrm{FeO}_{(\mathrm{s})} \\
\mathrm{FeO}_{(\mathrm{s})}+1 / 6 \mathrm{O}_{2(\mathrm{~g})}=1 / 3 \mathrm{Fe}_{3} \mathrm{O}_{4(\mathrm{~s})} \\
2 / 3 \mathrm{Fe}_{3} \mathrm{O}_{4(\mathrm{~s})}+1 / 6 \mathrm{O}_{2}+\mathrm{ZnO}_{(\mathrm{s})}=\mathrm{ZnFe}_{2} \mathrm{O}_{4(\mathrm{~s})}\end{array}$ \\
\hline 5 & - & $\begin{array}{c}\mathrm{Fe}_{(\mathrm{s})}+1 / 2 \mathrm{O}_{2(\mathrm{~g})}=\mathrm{FeO}_{(\mathrm{s})} \\
2 \mathrm{FeO}_{(\mathrm{s})}+1 / 2 \mathrm{O}_{2}+\mathrm{ZnO}_{(\mathrm{s})}=\mathrm{ZnFe}_{2} \mathrm{O}_{4(\mathrm{~s})}\end{array}$ \\
\hline
\end{tabular}
filter cake has formed zinc ferrite. While the proportions of these phases at the lower temperatures $\left(400^{\circ} \mathrm{C}\right.$ and $\left.600^{\circ} \mathrm{C}\right)$ were not large, this might be expected from the shrinking core behaviour that was observed in the samples. The phase analysis shows that the most likely phases being formed in

Table 3. Proposed reaction schemes for step 2 of the characteristic BOS filter cake behaviour during heating. 
Step 2 were hematite and zinc ferrite, which strongly supports Reaction Scheme 3.

The thermodynamics of the oxidation of the BOS filter cake was investigated using FactSage 7.0, using the FactPS and FTOxide databases. ${ }^{10)}$ The simple $\mathrm{Fe}-\mathrm{Zn}-\mathrm{O}$ system was examined in a $\log \left(\mathrm{pO}_{2}\right)$ - $\mathrm{T}$ phase diagrams for a nominal 16.7 mass\% $\mathrm{ZnO}$ in the BOS filter cake (Fig. 6). For the conditions considered in the reactivity testing $\left(\log \left(\mathrm{pO}_{2}\right)=-0.678,40<\mathrm{T}<1000^{\circ} \mathrm{C}\right)$, the stable phases are hematite and spinel. The composition of the spinel phase under these conditions was also examined using FactSage, and was found to be close to that of stoichiometric zinc ferrite $\left(\mathrm{ZnFe}_{2} \mathrm{O}_{4}\right)$. Additionally, it is known that wüstite is not stable below temperatures of $570^{\circ} \mathrm{C}$. ${ }^{12}$ ) This rules out reaction scheme 5 as reaction 8 is not thermodynamically favoured for most of the temperature range of Step 2. The results from the thermodynamic modelling strongly support

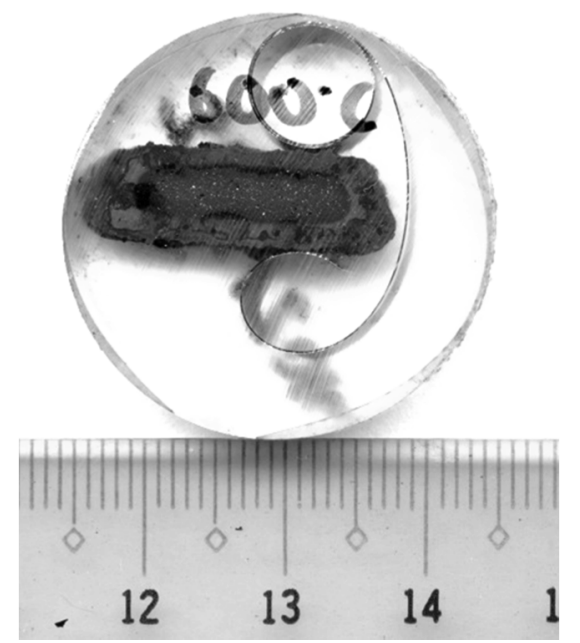

Fig. 5. Typical example of a rapidly cooled sample (from $600^{\circ} \mathrm{C}$ ) showing the shrinking core behaviour. reaction scheme 3 (forming both hematite and zinc ferrite), while ruling out scheme 5 .

The measured enthalpy of the peak associated with Step 2 was used to compare with the predicted enthalpy for each of the reaction schemes presented in Table 3. The energy (enthalpy) associated with the main oxidation peak in Fig. 4(d) was measured from the area under the DSC curves,

Table 4. Quantitative XRD results for iron and zinc bearing phases of rapidly cooled samples of BOS filter cake.

\begin{tabular}{cccccc}
\hline \multirow{2}{*}{ sample } & \multicolumn{5}{c}{ mass\% } \\
\cline { 2 - 6 } & $\begin{array}{c}\mathrm{Zincite} \\
\mathrm{ZnO}\end{array}$ & $\begin{array}{c}\text { Wüstite } \\
\mathrm{FeO}\end{array}$ & $\begin{array}{c}\text { Metallic } \\
\mathrm{Fe}\end{array}$ & $\begin{array}{c}\mathrm{Hematite}_{\mathrm{Fe}_{2} \mathrm{O}_{3}} \\
\mathrm{Fe}_{3} \mathrm{O}_{4}+ \\
\mathrm{ZnFe}_{2} \mathrm{O}_{4}\end{array}$ \\
\hline $\begin{array}{c}\text { Rapidly cooled } \\
\text { from } 400^{\circ} \mathrm{C}\end{array}$ & 11.6 & 18.5 & 10.0 & 9.7 & 50.3 \\
$\begin{array}{c}\text { Rapidly cooled } \\
\text { from } 600^{\circ} \mathrm{C}\end{array}$ & 8.3 & 17.9 & 3.6 & 15.1 & 55.1 \\
$\begin{array}{c}\text { Rapidly cooled } \\
\text { from } 800^{\circ} \mathrm{C}\end{array}$ & $<1$ & $<1$ & $<1$ & 33.9 & 65.0 \\
$\begin{array}{c}\text { Rapidly cooled } \\
\text { from } 1000^{\circ} \mathrm{C}\end{array}$ & $<1$ & $<1$ & $<1$ & 27.4 & 72.1 \\
\hline
\end{tabular}

Table 5. Key for the phase fields in Fig. 6.

\begin{tabular}{cc}
\hline Key & Phases present \\
\hline A & gas + Fe(liq) \\
B & gas + Fe(s) \\
C & Monoxide + gas \\
D & gas + Slag \\
E & Spinel + Slag \\
F & Slag + Monoxide \\
G & Monoxide + Zincite \\
H & Spinel + Zincite \\
\hline
\end{tabular}

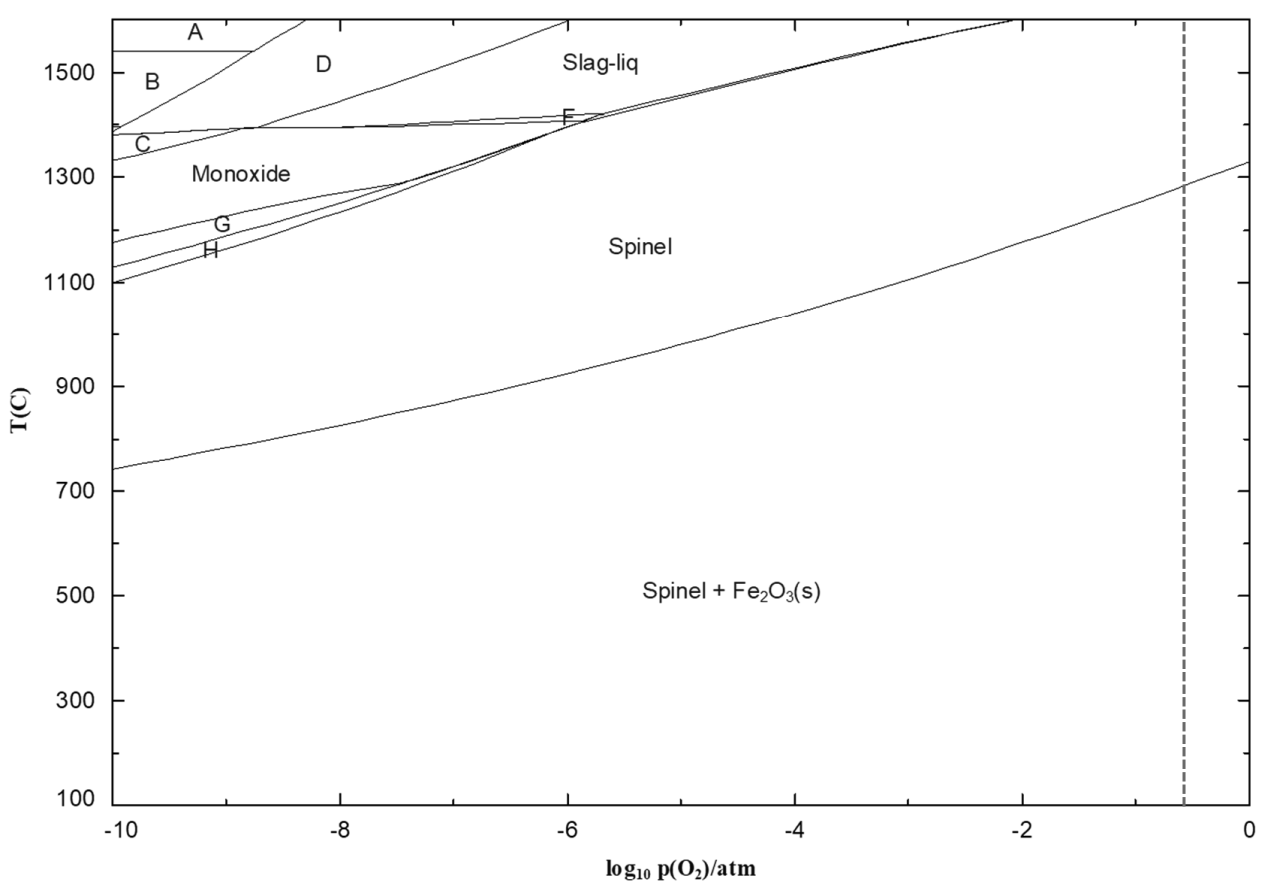

Fig. 6. Thermodynamic stability diagram for the iron-zinc-oxygen system for a ZnO content of $16.7 \%$ (taken from the XRF results, Table 1), as calculated using FactSage. ${ }^{10)}$ Key for the phase fields given in Table 5. 
using a Bézier baseline. ${ }^{13)}$

The predicted enthalpies were calculated using data from FactSage $^{10)}$ taking into account the initial composition of the sample and the measured weight change during the reaction. The proportions of wüstite, metallic iron and $\mathrm{ZnO}$ in the initial BOS filter cake samples were used in the prediction of the reaction enthalpy. The measured weight change that corresponded to the DSC peak was used to determine the amount of the BOS filter cake that reacted.

The comparison between the predicted and measured enthalpies for each reaction scheme is given in Table 6. Using the enthalpy values in Table 6 , an average root mean square (RMS) difference of $<2 \%$ was reported as a 'good' match between the enthalpies. Differences between the enthalpies in the range of 2 and $4 \%$ were reported as 'moderate' matches, while a difference $>4 \%$ was reported as a 'poor' match.

While many of the reaction schemes had reasonable matches between the measured and predicted enthalpies, the best match was for scheme 3, dealing with the formation of hematite and zinc ferrite. This result agrees well with the results from both the characterisation of the reacted BOS filter cake samples and the thermodynamic modelling.

The summary of all of these different approaches to identifying which reactions occurred in Step 2 is given in
Table 7. Each of the approaches, phase characterisation, thermodynamic modelling and enthalpy measurement, all led to the same finding, that Step 2 represents the full oxidation of the BOS filter cake to hematite and zinc ferrite (scheme 3). The different approaches used all gave consistent answers, increasing confidence in the findings.

\subsection{Step 3.}

The mass loss between $600^{\circ} \mathrm{C}$ and $770^{\circ} \mathrm{C}$ was accompanied by a small endothermic peak. This step was likely caused by calcination of one of the flux phases in the BOS filter cake. There are several flux phases that were expected to be found within the BOS filter cake. These include burnt and unburnt lime $\left(\mathrm{CaO}\right.$ and $\mathrm{CaCO}_{3}$, respectively), burnt dolomite (considered as a mixture of $\mathrm{CaO}$ and $\mathrm{MgO}$ ), and unburnt dolomite $\left(\mathrm{CaMg}\left(\mathrm{CO}_{3}\right)_{2}\right)$, all of which may be entrained with the off-gas in the $\mathrm{BOS}^{9)}$ ).

The thermodynamics of calcination of several fluxes was considered through the Gibbs free energy $\left(\Delta \mathrm{G}^{\circ}\right)$ of simple reactions, given in Eqs. (10)-(14), using the FactSage ${ }^{10)}$ database. If $\Delta \mathrm{G}^{\circ}<0 \mathrm{~kJ} / \mathrm{mol}$ then the reaction was considered possible at the temperature considered. Burnt fluxes are expected to have hydrated during the wet scrubbing and separation processes and were considered as $\mathrm{Ca}(\mathrm{OH})_{2}$ and $\mathrm{Mg}(\mathrm{OH})_{2}$. The temperatures at which different calcining

Table 6. Comparison between the measured and predicted enthalpies for Step 2 in the self-sintering process.

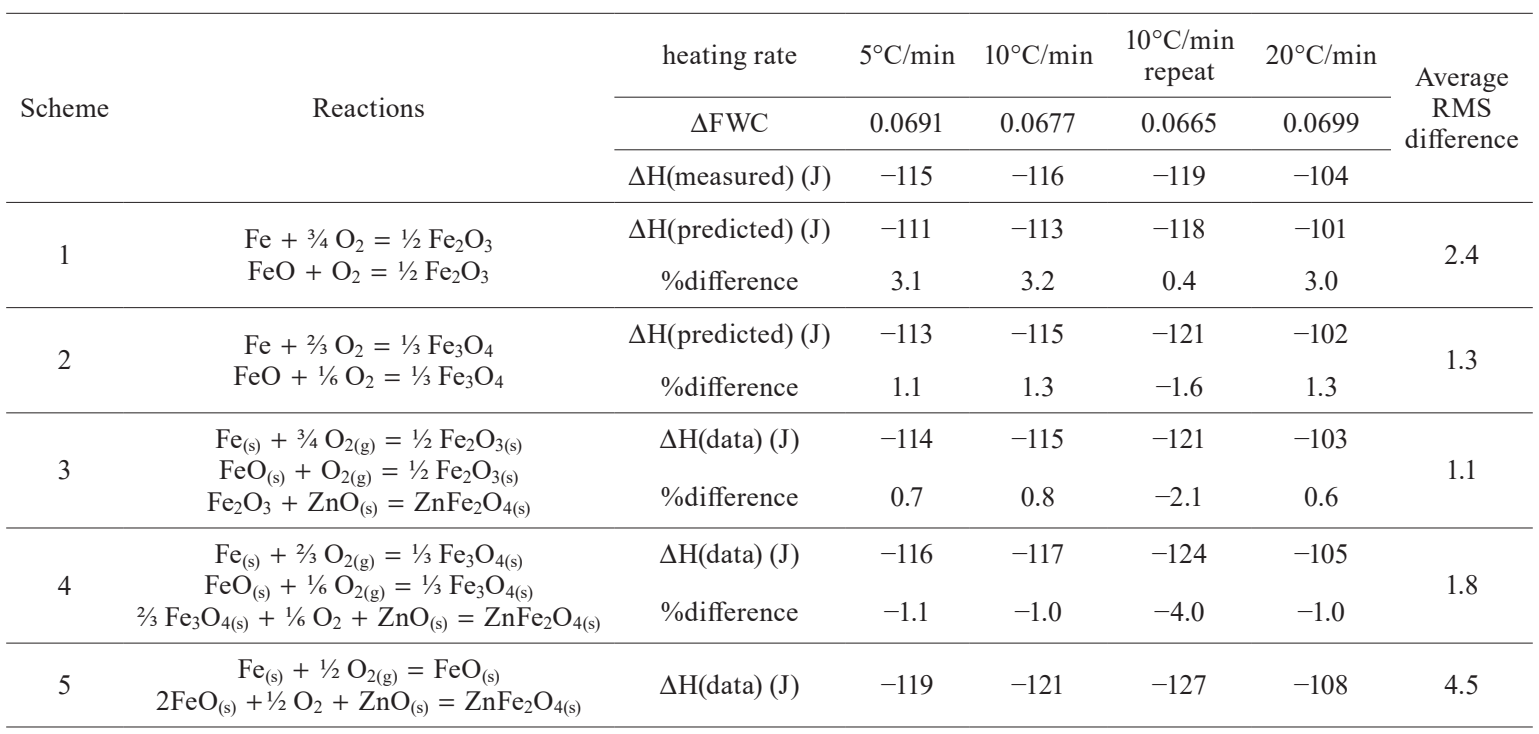

Table 7. Summary of the findings of the analysis of different reaction schemes for Step 2 in the self-sintering process.

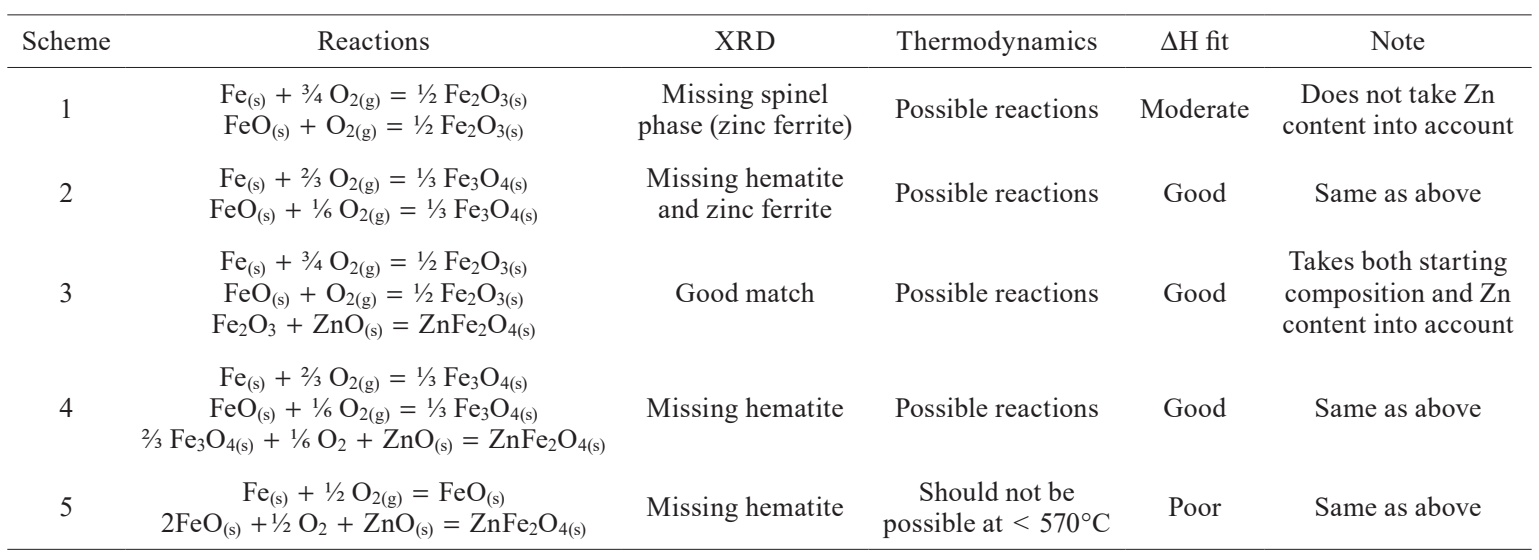


reactions become thermodynamically possible are given in Table 8.

$$
\begin{array}{r}
\mathrm{CaCO}_{3(\mathrm{~s})}=\mathrm{CaO}_{(\mathrm{s})}+\mathrm{CO}_{2(\mathrm{~g})} \\
\mathrm{Ca}(\mathrm{OH})_{2(\mathrm{~s})}=\mathrm{CaO}_{(\mathrm{s})}+\mathrm{H}_{2} \mathrm{O}_{(\mathrm{g})} \\
\mathrm{CaMg}\left(\mathrm{CO}_{3}\right)_{2(\mathrm{~s})}=\mathrm{CaO}_{(\mathrm{s})}+\mathrm{MgO}_{(\mathrm{s})}+2 \mathrm{CO}_{2(\mathrm{~g})} \ldots \\
\mathrm{CaMg}\left(\mathrm{CO}_{3}\right)_{2(\mathrm{~s})}=\mathrm{CaCO}_{3(\mathrm{~s})}+\mathrm{MgO}_{(\mathrm{s})}+\mathrm{CO}_{2(\mathrm{~g})} \ldots \\
\mathrm{Mg}(\mathrm{OH})_{2(\mathrm{~s})}=\mathrm{MgO}_{(\mathrm{s})}+\mathrm{H}_{2} \mathrm{O}_{(\mathrm{g})}
\end{array}
$$

For the temperature range involved in Step 3 (600$770^{\circ} \mathrm{C}$ ), calcination of unburnt dolomite, hydrated dolomite and hydrated lime (Eqs. (10)-(13)) are thermodynamically possible, while the calcination of calcium carbonate (unburnt lime, Eq. (9)) is not. Hence, the mass loss and endothermic reactions associated with Step 3 are likely to be the calcination of hydrated fluxes and unburnt dolomite.

\subsection{Step 4 .}

This step represents a small weight gain with an associated small exothermic peak. It is possible that this may represent the final oxidation of the larger wüstite and metallic iron particles within the BOS filter cake.

\subsection{Step 5.}

Similarly to Step 3, this step involved a slight weight

Table 8. Temperature at which $\Delta \mathrm{G}^{\circ}=0 \mathrm{~kJ} / \mathrm{mol}$ for the calcination of different fluxes.

\begin{tabular}{ccc}
\hline Flux & Reaction & $\mathrm{T}\left(\Delta \mathrm{G}^{\circ}=0\right)$ \\
\hline Limestone, $\mathrm{CaCO}_{3}$ & $\mathrm{CaCO}_{3(\mathrm{~s})}=\mathrm{CaO}_{(\mathrm{s})}+\mathrm{CO}_{2(\mathrm{~g})}$ & $894^{\circ} \mathrm{C}$ \\
Hydrated lime, $\mathrm{Ca}(\mathrm{OH})_{2}$ & $\mathrm{Ca}(\mathrm{OH})_{2(\mathrm{~s})}=\mathrm{CaO}_{(\mathrm{s})}+\mathrm{H}_{2} \mathrm{O}_{(\mathrm{g})}$ & $525^{\circ} \mathrm{C}$ \\
& $\mathrm{CaMg}\left(\mathrm{CO}_{3}\right)_{2(\mathrm{~s})}=\mathrm{CaO}_{(\mathrm{s})}+\mathrm{MgO}_{(\mathrm{s})}+2 \mathrm{CO}_{2(\mathrm{~g})}$ & $643^{\circ} \mathrm{C}$ \\
Dolomite, $\mathrm{CaMg}\left(\mathrm{CO}_{3}\right)_{2}$ & $\mathrm{CaMg}\left(\mathrm{CO}_{3}\right)_{2(\mathrm{~s})}=\mathrm{CaCO}_{3(\mathrm{~s})}+\mathrm{MgO}_{(\mathrm{s})}+\mathrm{CO}_{2(\mathrm{~g})}$ & $425^{\circ} \mathrm{C}$ \\
Hydrated magnesia, $\mathrm{Mg}(\mathrm{OH})_{2}$ & $\mathrm{Mg}(\mathrm{OH})_{2(\mathrm{~s})}=\mathrm{MgO}_{(\mathrm{s})}+\mathrm{H}_{2} \mathrm{O}_{(\mathrm{g})}$ & $267^{\circ} \mathrm{C}$ \\
\hline
\end{tabular}

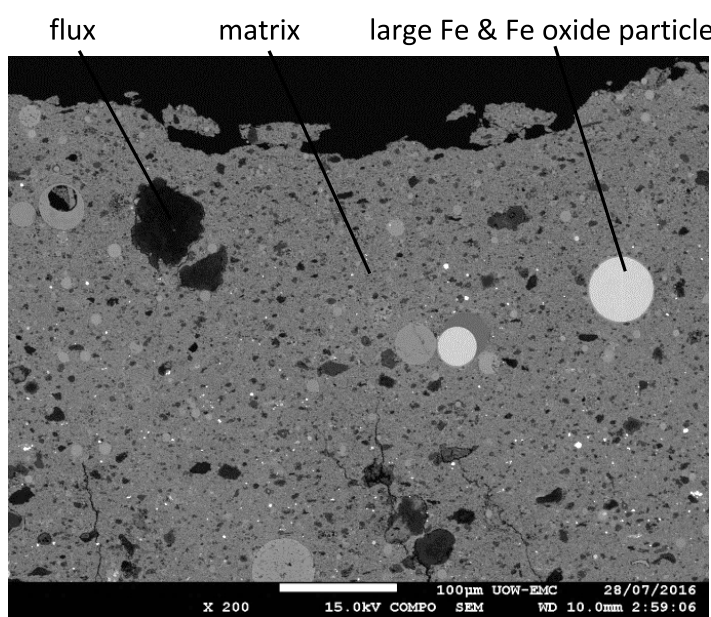

(a)

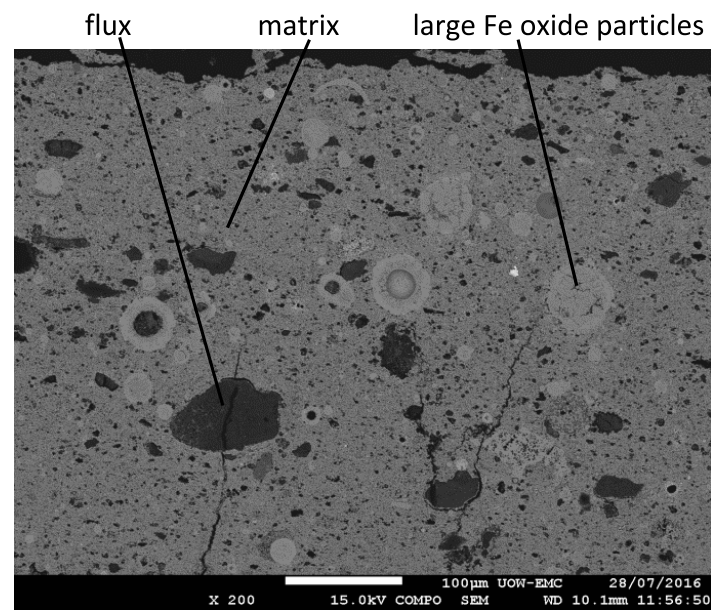

(c)

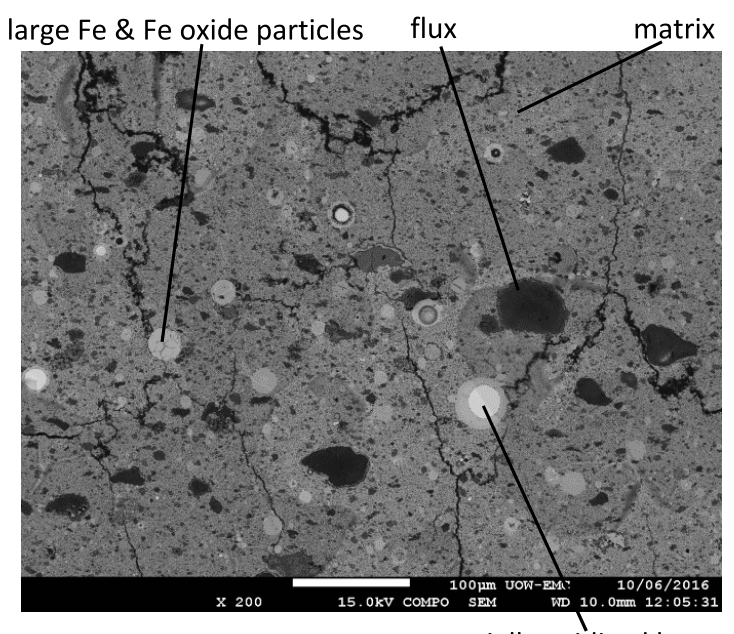

(b)

partially oxidised large Fe particles

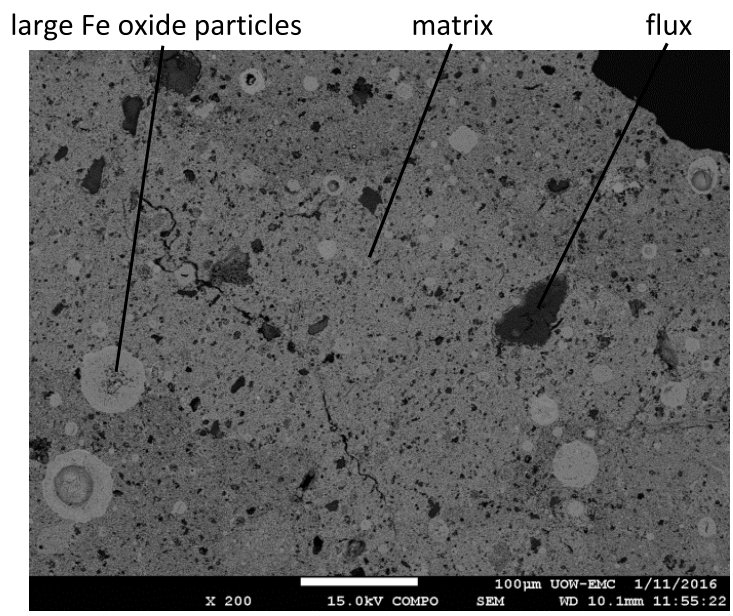

(d)

Fig. 7. Low magnification back-scattered SEM images of the outer product layer of BOS filter cake samples rapidly cooled from (a) $400^{\circ} \mathrm{C}$; (b) $600^{\circ} \mathrm{C}$; (c) $800^{\circ} \mathrm{C}$; and (d) $1000^{\circ} \mathrm{C}$ in air. The scale bars are $100 \mu \mathrm{m}$. 
loss at temperatures above $900^{\circ} \mathrm{C}$. Referring again to Table 8 , the calcination of unburnt lime $\left(\mathrm{CaCO}_{3}\right.$, Eq. (9)) only becomes possible at temperatures above $894^{\circ} \mathrm{C}$. This temperature corresponds well with the temperature range for this step, likely indicating that Step 5 is the calcination of unburnt lime.

\subsection{Bonding in Self-sintered and Reacted Samples}

The microstructures of the rapidly cooled, post-reaction samples were examined by SEM-EDS. Due to the shrinking core type behaviour seen in the rapidly cooled samples (Fig. 5), they were only examined in the outer product layer. For all samples up to $1000^{\circ} \mathrm{C}$, at low magnifications (Fig. 7), there was not much change in the microstructures from the unreacted material. Larger metallic iron particles in the microstructure showed evidence of increasing oxidation as the temperature increased to $800^{\circ} \mathrm{C}$. Oxidation for these particles is shown by the formation of a darker ring surrounding a brighter metallic iron core (Fig. 7(b)), or by a lack of bright metallic particles in the structure at all (Figs. 7(c) and 7(d)).

At higher magnifications (Fig. 8), bonding between the fine iron oxide particles in the matrix of the BOS filter cake could be observed. The bonding in the reacted filter cake samples was primarily due to particle-particle bonds forming between the fine iron oxide particles. These particleparticle bonds were evidenced by the formation of small (1-2 particles wide and several particles in length) bonded entities within the matrix of the BOS filter cake. At low temperatures, $<400^{\circ} \mathrm{C}$, there was limited bonding between the particles. The amount of bonding increased with increasing temperature to $1000^{\circ} \mathrm{C}$. There may be local particle surface temperatures not represented by the bulk temperatures. Interfacial energies associated with the very fine initial particle size will also promote sintering as well as allowing reaction at low temperature.

Comparing these microstructures with those found in the self-sintered samples taken from the stockpiles (Fig. 9) can help to inform what conditions are required to form sintered BOS filter cake that has adequate strength for recycling to the BOS. For this recycling route, the self-sintered BOS filter cake needs to be able to be sized to $>4 \mathrm{~mm}$. There were obvious similarities between the microstructures observed in the samples taken from the stockpiles (Fig. 9) and those in samples oxidised under controlled conditions in the laboratory (Fig. 8). It appears as though exposure of the BOS filter cake to temperatures above $600^{\circ} \mathrm{C}$ under oxidising conditions should give the BOS filter cake sufficient strength for

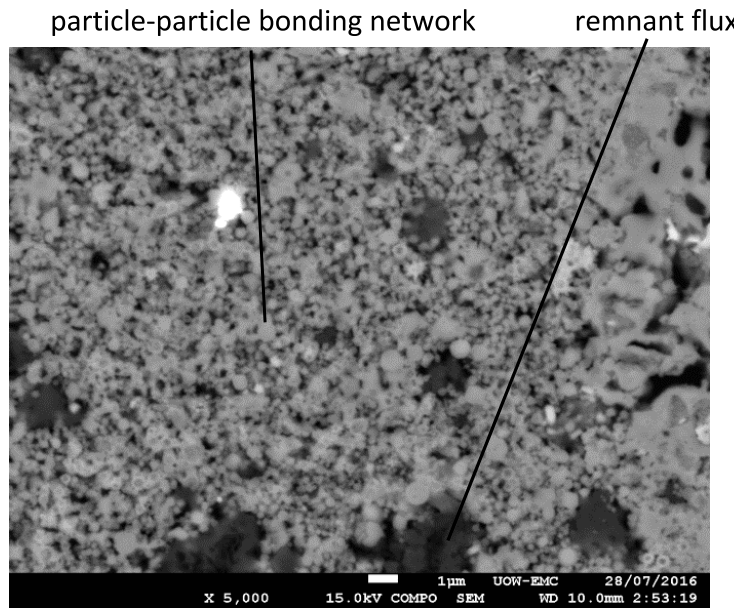

(a)

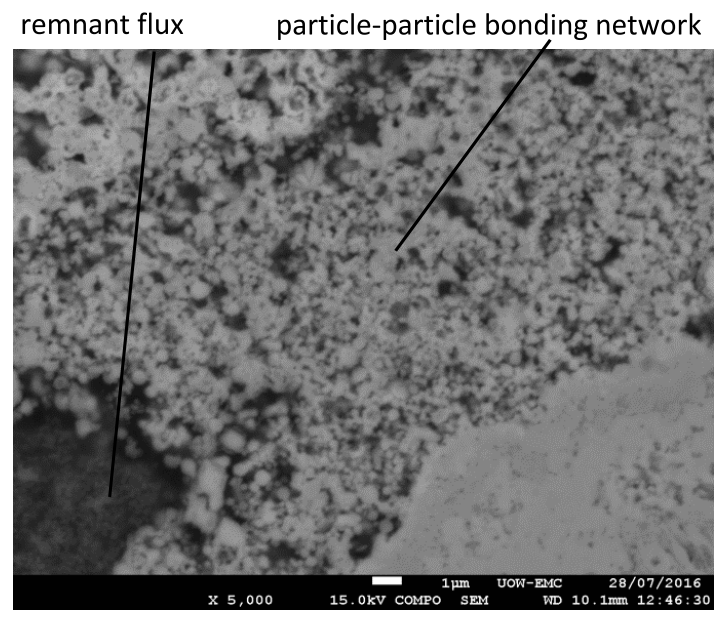

(c)

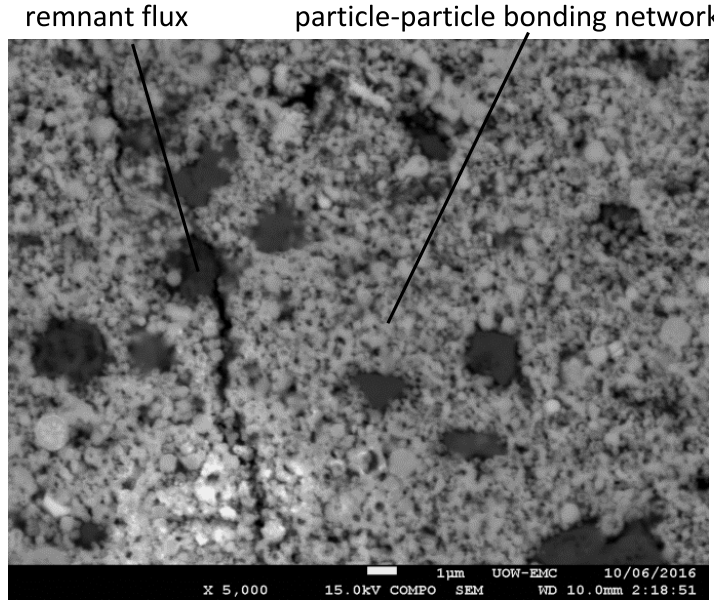

(b)

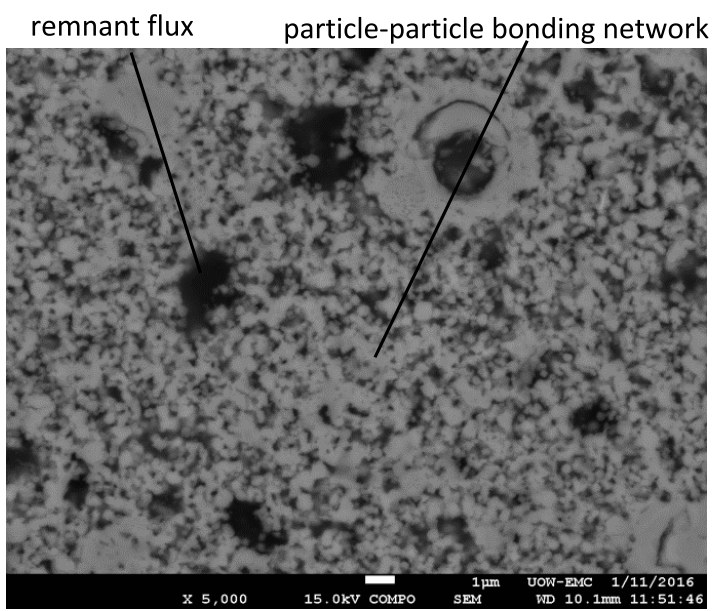

(d)

Fig. 8. High magnification SEM images of the outer product layer of BOS filter cake samples rapidly cooled from (a) $400^{\circ} \mathrm{C}$; (b) $600^{\circ} \mathrm{C}$; (c) $800^{\circ} \mathrm{C}$; and (d) $1000^{\circ} \mathrm{C}$ in air. The scale bars are $1 \mu \mathrm{m}$. 


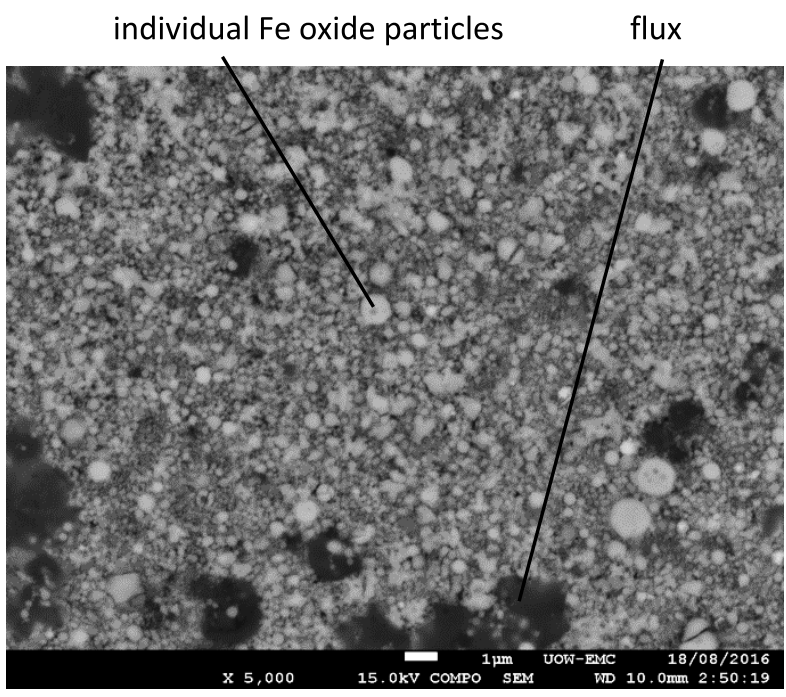

(a)

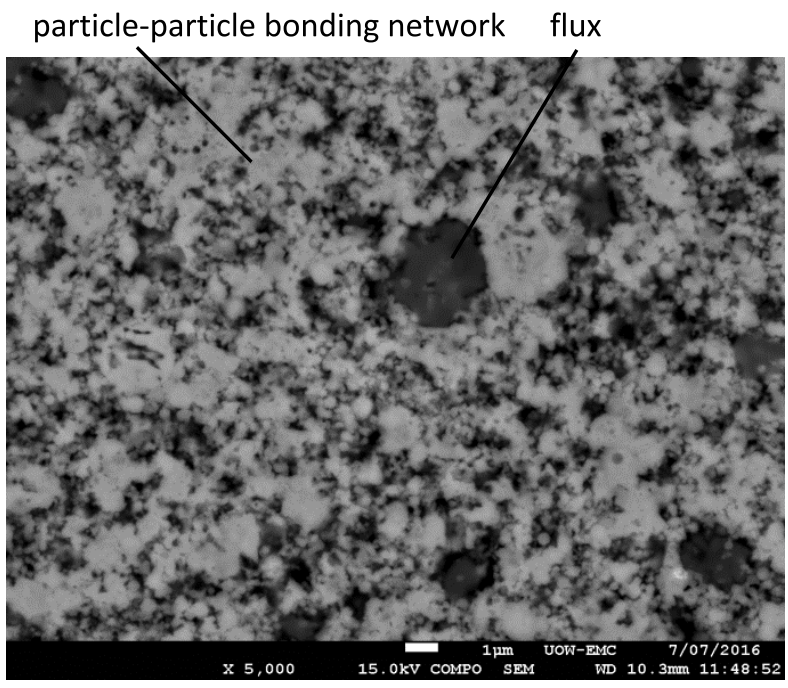

(b)

Fig. 9. High magnification SEM images of self-sintered BOS filter cake samples. (a) Inadequately bonded, unsuitable for recycling; and (b) adequately bonded, suitable for recycling. The scale bars are $1 \mu \mathrm{m}$.

transport and recycling in the BOS.

\section{Conclusions}

The oxidation of BOS filter cake from 100 to $1000^{\circ} \mathrm{C}$ has been studied with an emphasis on better understanding the self-sintering process. The aim of the study was to gain an understanding of what phenomena were occurring during the self-sintering process, both in terms of what reactions occurred, and how strength was developed in the filter cake during self-sintering.

The reactivity of the BOS filter cake was studied by artificially initiating the self-sintering process by heating in air in both a TGA and a TGA-DSC, and measuring the weight change and energy given off during the process. This was followed by characterisation of the reacted samples. The BOS filter cake showed a characteristic behaviour during heating in air, consisting of largely sequential drying, oxidation and calcination events.

Reaction between the metallic iron and wüstite in the BOS filter cake and air started when the filter cake was dry and the temperature approximately $120^{\circ} \mathrm{C}$. The oxidation of the BOS filter cake was largely complete by $500-600^{\circ} \mathrm{C}$. Phase analysis, thermodynamic modelling and measurement of the enthalpy of reaction were all used to propose the likely reactions occurring during self-sintering. Each of these assessment approaches gave similar findings. The likely reactions in the $120-600^{\circ} \mathrm{C}$ temperature range were found to be the oxidation of metallic iron and wüstite to hematite and zinc ferrite. These exothermic oxidation reactions at low temperatures are believed to provide the energy required to heat the stockpiles and drive self-sintering.

Bonding within the filter cake was from a network of particle-particle bonds that formed between the very fine iron oxide particles in the matrix during oxidation at elevated temperatures. Exposure of the BOS filter cake to temperatures between $600-800^{\circ} \mathrm{C}$ under oxidising conditions is likely sufficient to form adequately strong material for transport and recycling in the BOS. Fluxes played an insignificant role in the development of the bonding within the filter cake.

\section{Acknowledgements}

Funding from the Australian Research Council Industrial Transformation Research Hubs Scheme (Project Number IH130100017) is gratefully acknowledged. This research used equipment funded by Australian Research Council grant LE0882813 and located at the UOW Electron Microscopy Centre.

\section{REFERENCES}

1) R. L. Nyirenda: Miner. Eng., 4 (1991), 1003

2) D. Hleis, I. Fernández-Olmo, F. Ledoux, A. Kfoury, L. Courcot, T. Desmonts and D. Courcot: J. Hazard. Mater., 250-251 (2013), 246.

3) H. T. Makkonen, J. Heino, L. Laitila, A. Hiltunen, E. Pöyliö and J. Härkki: Resour. Conserv. Recycl., 35 (2002), 77.

4) H. M. Ahmed, A. Persson, L. S. Ökvist and B. Björkman: ISIJ Int., 55 (2015), 2082.

5) J. Steer, C. Grainger, A. Griffiths, M. Griffiths, T. Heinrich and A. Hopkins: Ironmaking Steelmaking, 41 (2014), 61.

6) S. Kelebek, S. Yörük and B. Davis: Miner. Eng., 17 (2004), 285.

7) R. J. Longbottom, B. J. Monaghan, G. Zhang, S. J. Chew and D. J. Pinson: Proc. 7th European Coke and Ironmaking Cong., ASMET, Leoben, (2016), 1017.

8) R. J. Longbottom, B. J. Monaghan, G. Zhang, S. J. Chew and D. J. Pinson: Chemeca 2016: Chemical Engineering - Regeneration, Recovery and Reinvention, RACI, Melbourne, (2016), 352.

9) L. Nedar: Steel Res., 67 (1996), 320.

10) C. W. Bale, E. Bélisle, P. Chartrand, S. Decterov, G. Eriksson, A. Gheribi, K. Hack, I.-H. Jung, J. Melancon, A. D. Pelton, S. Petersen and C. Robelin: Celebrating the Megascale: Proc. the Extraction and Processing Division Symp. on Pyrometallurgy in Honor of David G. C. Robertson, ed. by P. Mackey et al., TMS, Warrendale, PA, (2014), 114.

11) O. Levenspiel: Chemical Reaction Engineering, 2nd ed., Wiley, New York, (1972), 361.

12) A. Muan and E. F. Osborn: Phase Equilibria Among Oxides in Steelmaking, Addison-Wesley Publishing, Reading, (1965), 25.

13) Y. J. Ahn, Y. S. Kim and Y. Shin: J. Comput. Appl. Math., 167 (2004), 405. 